\section{Improving Fruit Quality of Apricot by Means of Preharvest Benzyladenine and Benzyladenine Plus Gibberellin Applications}

\author{
Fatih Ali Canli ${ }^{1,4}$, Murat Sahin ${ }^{1}$, Nurettin Temurtas ${ }^{2}$, and \\ Mustafa Pektas ${ }^{3}$
}

\begin{abstract}
Additional Index words. BA, firmness, fruit size, $\mathrm{GA}_{4+7}$, Prunus armeniaca, SSC
Summary. Applications that could improve apricot (Prunus armeniaca) fruit size and quality would enhance their marketability. In this study, the effects of preharvest benzyladenine (BA) and BA plus gibberellin (GA) applications on fruit quality of 'Alyanak' apricot were investigated. $\mathrm{BA}(50,100$, and $150 \mathrm{ppm})$ and $\mathrm{BA}$ $+\mathrm{GA}_{4+7}(12.5,25$, and $50 \mathrm{ppm})$ were applied at the beginning of pit hardening stage. When fruit reached their maturity, samples were harvested and evaluated in terms of: weight, size, firmness, soluble solids content (SSC), acidity, and pH. Fruit treated with BA were significantly heavier and larger than fruit not treated, and there were significant differences in fruit size within the BA-treated fruit. The heaviest and the largest fruit were obtained from 100 to $150 \mathrm{ppm} \mathrm{BA} \mathrm{concentra-}$ tions. BA $+\mathrm{GA}_{4+7}$ treatments did not affect fruit size. Application of $100 \mathrm{ppm} \mathrm{BA}$ and $25 \mathrm{ppm} \mathrm{BA}+\mathrm{GA}_{4+7}$ increased fruit firmness at harvest. SSC, pH, and acidity were unaffected by the applications. The results obtained in this study showed a practical benefit of a single application of $\mathrm{BA}$ at the end of pit hardening for improving apricot quality. Fruit treated with the optimum dose of BA (100 ppm) were larger and firmer than untreated fruit.
\end{abstract}

A

pricot is a nutritious fruit being cultivated in temperate zones of the world (Bhat et al., 2013). Fruit quality and consumer acceptance of apricot is mostly defined by fruit firmness, size, flavor, and attractiveness. Fruit size and firmness are also the key factors affecting yield, marketability, and crop value for producers (Roussos et al., 2011). Fruit size is determined by genetic, cultural, and environmental factors (Badanes et al., 1998; Dirlewanger et al., 1999; Mratinic et al., 2011). It has long been established that fruit size can be increased by various cultural applications, such as external chemical treatments in the early phases of the fruit development (Canli and Orhan, 2009; Kappel and MacDonald, 2002).

Fruit size at harvest time is largely affected by cell division and cell enlargement at the initial periods

We gratefully acknowledge the fund provided by Suleyman Demirel University and the technical assistance contributed by Egirdir Horticultural Research Institute, Egirdir, Isparta, Turkey.

${ }^{1}$ Department of Biotechnology, Faculty of Agriculture, Suleyman Demirel University, 32260, Isparta, Turkey

${ }^{2}$ Egirdir Horticultural Research Institute, Egirdir, Isparta, Turkey

${ }^{3}$ West Mediterranean Development Agency, Isparta, Turkey

${ }^{4}$ Corresponding author. E-mail: fatihcanli@sdu.edu.tr. of fruit development (Bohner and Bangerth, 1988; Zhang et al., 2005). Plant growth regulators [PGRs (auxins, gibberellins, and cytokinins)] are used in many fruit production systems to increase fruit size (Gillaspy et al., 1993; Jackson, 2003; Ozga and Reinecke, 2003).

Gibberellic acid $\left(\mathrm{GA}_{3}\right)$ is used extensively in fruit species to increase fruit size including grape [Vitis vinifera (Zahedi et al., 2013; Zoffoli et al., 2009)] and sweet cherry [Prunus avium (Canli and Orhan, 2009; Choi et al., 2002; Clayton et al., 2006; Horvitz et al., 2003; Kappel and MacDonald, 2002; Kupferman, 1989; Lenahan et al., 2006; Sive and Resnizky, 1988; Usenik et al., 2005)]. The synthetic auxin 3,5,6-trichloro-2-pyridyloxyacetic acid $(3,5,6$-TPA) improved color and size of apricot when it was applied during the pit hardening phase (Bregoli et al., 2010). A preharvest spray of $25 \mathrm{mg} \cdot \mathrm{L}^{-1}$ 2,4-dichlorophenoxypropionic acid (2,4-DP) during pit hardening also improved fruit size and advanced fruit maturation in apricot (Agusti et al., 1994).

After harvest, softening of the apricot fruit adversely affects its marketability and value. $\mathrm{GA}_{3}$ treatments in sweet cherry delayed fruit ripening (Andrews and Shulin, 1995; Canli and Orhan, 2009; Choi et al., 2002; Demirsoy and Bilgener, 2000; Horvitz et al., 2003; Kappel and MacDonald, 2002; Usenik et al., 2005; Webster et al., 2006) and increased fruit firmness (Canli and Orhan, 2009; Choi et al., 2002; Einhorn et al., 2013; Kappel and MacDonald, 2002). Delayed fruit ripening enabled fruit to stay on trees longer resulting in increased fruit size and fruit firmness (Ju et al., 1999). Fruit firmness was increased by 100 ppm $\mathrm{GA}_{3}$ applied $21 \mathrm{~d}$ before harvest in 'Patterson' apricot (Southwick and Yeager, 1995).

Endogenous cytokinins stimulate cell division in young fruit (Stern et al., 2002). The effects of preharvest application of $\mathrm{GA}_{3}, \mathrm{GA}_{3}+2,4-$ dichlorophenoxyacetic acid (2,4-D) + 1-napthaleneacetic acid (NAA), and $\mathrm{GA}_{4+7}+\mathrm{BA}$ on fruit size of smallfruited summer pear (Pyrus communis) varieties were studied (Stern et al., 2007). While $\mathrm{GA}_{3}$ alone was not effective in increasing fruit sizes of pear, $\mathrm{GA}_{4+7}+\mathrm{BA}$ application $14 \mathrm{~d}$ after full bloom increased fruit size. Similarly, BA was very effective in increasing fruit size of 'Le Conte' pear, but fruit size was not positively influenced by $\mathrm{GA}_{3}$ application (Yehia and Hassan, 2005). $\mathrm{BA}+\mathrm{GA}_{4+7}$ applications also improved size of apple (Malus $\times$ domestica) (Dennis, 2000).

Preharvest PGR applications that could improve fruit size, color, and precocity of apricot would enhance

\begin{tabular}{llll}
\hline $\begin{array}{l}\text { Units } \\
\text { To convert U.S. to SI, } \\
\text { multiply by }\end{array}$ & U.S. unit & SI unit & $\begin{array}{l}\text { To convert SI to U.S., } \\
\text { multiply by }\end{array}$ \\
\hline 10 & $\%$ & $\mathrm{~g} \cdot \mathrm{L}^{-1}$ & 0.1 \\
29.5735 & $\mathrm{fl} \mathrm{oz}$ & $\mathrm{mL}$ & 0.0338 \\
0.3048 & $\mathrm{ft}$ & $\mathrm{m}$ & 3.2808 \\
25.4 & inch $(\mathrm{es})$ & $\mathrm{mm}$ & 0.0394 \\
273.4033 & inch/ft & $\mathrm{mm} \cdot \mathrm{m}^{-2}$ & 0.0037 \\
4.4482 & lbf & $\mathrm{N}$ & 0.2248 \\
28.3495 & $\mathrm{oz}$ & $\mathrm{g}$ & 0.0353 \\
1 & $\mathrm{ppm}$ & $\mathrm{mg} \cdot \mathrm{L}^{-1}$ & 1 \\
$\left({ }^{\circ} \mathrm{F}-32\right) \div 1.8$ & ${ }^{\circ} \mathrm{F}$ & ${ }^{\circ} \mathrm{C}$ & $\left({ }^{\circ} \mathrm{C} \times 1.8\right)+32$
\end{tabular}


their marketability. While there are a few reports on the effects of $\mathrm{BA}$ and $\mathrm{GA}_{4+7}+\mathrm{BA}$ on the fruit size and quality of pome fruit, there are no reports on the effects of these PGRs on the size and quality of apricots. Therefore, the aim of this study was to investigate the effects of $\mathrm{BA}$ and $\mathrm{GA}_{4+7}+\mathrm{BA}$ on fruit quality of 'Alyanak' apricot.

\section{Materials and methods}

This experiment was conducted on 21 May 2009 and 21 May 2010 on 9- and 10-year-old, respectively, 'Alyanak' apricot trees planted at $5 \times$ $5 \mathrm{~m}$ and grown in loamy soil in a commercial orchard in Asagi Kasikara (lat. $38^{\circ} 17^{\prime} 49.68^{\prime \prime} \mathrm{N}$, long. $30^{\circ} 50^{\prime} 33.78^{\prime \prime} \mathrm{E}$, altitude $\left.1025 \mathrm{~m}\right)$, Isparta, Turkey. The total annual precipitation in the Asagi Kasikara region was $535.0 \mathrm{~mm} \cdot \mathrm{m}^{-2}$, with a mean minimum temperature of $-2.0{ }^{\circ} \mathrm{C}$ and a mean maximum annual temperature of $30.5^{\circ} \mathrm{C}$ [50-year average (1960$2010)]$. The coldest months were December, January, and February, and the warmest months were July and August, with the lowest precipitation recorded. As provided by the above data, the climate of the region presents warm dry summers and cold winters. The experiment was conducted in the same orchard and in the same trees each year. Since the soil type of the orchard and the tree sizes were uniform, the experiment was designed in a completely randomized design with three single-tree replicates for each treatment.

The trees were sprayed with a single application of 50,100 , or 150 ppm BA [Exilis (20 g. $\left.\mathrm{L}^{-1} \mathrm{BA}\right)$; Fine Agrochemicals, Worcester, UK] and $12.5,25$, or 50 ppm BA + $\mathrm{GA}_{4+7}$ [Perlan (18 g. $\mathrm{L}^{-1} \mathrm{GA}_{4+7}$ and $18 \mathrm{~g} \cdot \mathrm{L}^{-1}$ BA), Fine Agrochemicals] using a handgun sprayer when the fruit were at their pit hardening stage (29 $\mathrm{d}$ before harvest) of development on a nonwindy day in the afternoon. All spray treatments, including the water control alone, included polyethylene glycol sorbitan monolaurate surfactant (Tween-20; Sigma-Aldrich, St. Louis, MO).

When control fruit reached their maturity (in terms of color, SSC, firmness, and taste), random samples of 80 (20 fruit from each of the four sides of a tree) fruit per tree for each treatment were harvested and fruit quality was evaluated in terms of weight, size, firmness, SSC, acidity, and $\mathrm{pH}$.

Fruit weight was measured using a digital balance (model SBA 51; Scaltec Instruments, Goettingen, Germany). Fruit diameter and fruit length were determined using a digital caliper (Absolute 500-196-20; Mitutoyo, Aurora, IL). Fruit firmness was measured on the equatorial region at the fruit's maximum width after $\approx 1 \mathrm{~mm}$ of the skin was removed, using a firmness tester (model FT 001 Fruit Texture Analyser; Gullimex, Alfonsine, Italy) equipped with a $4.94-\mathrm{mm}$ probe. The soluble solids concentration was determined using a refractometer (model N.O.W. 507-1; Nippon Optical Works, Tokyo, Japan) from the juice after fruit firmness measurements. Titratable acid (TA) content was determined by titrating $10 \mathrm{~mL}$ fruit juice up to $\mathrm{pH} 8.1$ using $0.1 \mathrm{~N}$ sodium hydroxide $(\mathrm{NaOH})$. The acidity was calculated from the amount of $\mathrm{NaOH}$ used and expressed as percentage of citric acid. The fruit $\mathrm{pH}$ was measured using a digital $\mathrm{pH}$ meter (model pH 330; WTW, Weilheim, Germany).

The data on fruit weight, fruit size, fruit firmness, SSC, acidity, and $\mathrm{pH}$ obtained from averages of 2 years were analyzed using SAS (version 9.0; SAS Institute, Cary, NC) statistical software. Duncan's multiple range test was used to compare significant differences among treatment.

\section{Results}

The effects of PGR treatments on fruit weight, diameter, length, firmness (Table 1), and acidity (Table 2 ) were significant, but no differences were observed between control and treated fruit with regard to fruit SSC and pH (Table 2).

Fruit weight of BA-treated fruit was significantly higher than that of untreated fruit and $\mathrm{BA}+\mathrm{GA}_{4+7^{-}}$ treated fruit (Table 1 ). There were also significant differences in fruit weight within the BA-treated fruit, and the highest fruit weights were obtained from 100 to 150 ppm BA applications. $\mathrm{BA}+\mathrm{GA}_{4+7}$ treatments did not affect fruit weight (Table 1 ). Fruit treated with 100 or 150 ppm BA were significantly larger than both untreated fruit and the rest of the treated fruit (Table 1). Fruit treated with BA was significantly longer than fruit not treated and fruit treated with 25 and 50 ppm BA $+\mathrm{GA}_{4+7}$ (Table $1)$. There were also significant differences in fruit length within the BAtreated fruit, and the highest fruit length was obtained at 100 ppm BA (Table 1).

The effects of PGRs on fruit firmness were significant and mid concentrations of PGRs (25 ppm BA + $\mathrm{GA}_{4+7}$ and 100 ppm BA) improved fruit firmness of 'Alyanak' apricot (Table 1). No further improvements in fruit firmness were observed when PGR rates increased (Table 1 ).

PGR treatment significantly affected TA content of the fruit, and there were significant differences in TA content within the PGR-treated fruit. None of the treated fruit had higher TA content than control (Table 2).

\section{Discussion}

The fruit size and firmness are important quality parameters affecting customer preferences and fruit value in apricot (Bregoli et al., 2010). In this study, the fruit weight and size of 'Alyanak' apricot were both improved by all rates of $\mathrm{BA}$ applied in a single application at the end of pit hardening. These results are in agreement with other researchers who reported that $\mathrm{BA}, \mathrm{BA}+\mathrm{GA}_{4+7}$, or thidiazuron applications increased size of pear fruit (Stern and Flaishman, 2003; Stern et al., 2003, 2007; Yehia and Hassan, 2005). The BA application (100 ppm BA) after full bloom contributed to the size increase in 'Spadona' and 'Coscia' pear (Stern and Flaishman, 2003). The role of BA in improving fruit weight and fruit size may be due to its role in increasing cell division during the early stages of fruit development (Stern et al., 2007), while the promotion of fruit size by GA treatment may be due to its role in increasing cell enlargement (Pharis and King, 1995).

Increasing fruit firmness is one of the most frequent effects of preharvest BA, GA, and BA plus GA applications in fruit crops (Canli and Orhan, 2009; Facteau, 1986; Kappel and MacDonald, 2002; Stern et al., 2007; Usenik et al., 2005). Spraying 'Alyanak' apricot with 25 ppm BA + $\mathrm{GA}_{4+7}$ and 100 ppm BA improved the fruit firmness. The role of GA in improving fruit firmness in this study is in accordance with the findings of the other researchers (Canli and 
Table 1. Effect of preharvest foliar applications of benzyladenine (BA) and BA + gibberellins $\left(\mathrm{GA}_{4+7}\right)$ on fruit weight, length, and firmness of 'Alyanak' apricot at harvest $(n=80){ }^{\mathrm{z}}$

\begin{tabular}{lccccc}
\hline Treatment & $\begin{array}{c}\text { Concn } \\
(\mathbf{p p m})^{\mathbf{y}}\end{array}$ & $\begin{array}{c}\text { Fruit wt } \\
(\mathbf{g})^{\mathrm{y}}\end{array}$ & $\begin{array}{c}\text { Fruit diam } \\
(\mathbf{m m})^{\mathrm{y}}\end{array}$ & $\begin{array}{c}\text { Fruit length } \\
(\mathbf{m m})^{\mathbf{y}}\end{array}$ & $\begin{array}{c}\text { Fruit } \\
\text { firmness }(\mathbf{l b f})^{\mathrm{y}}\end{array}$ \\
\hline Control & 0 & $43.22 \mathrm{c}^{\mathrm{x}}$ & $40.55 \mathrm{~b}$ & $42.95 \mathrm{~d}$ & $4.09 \mathrm{bc}$ \\
$\mathrm{BA}+\mathrm{GA}_{4+7}$ & 12.5 & $43.65 \mathrm{c}$ & $40.05 \mathrm{~b}$ & $44.03 \mathrm{~cd}$ & $3.21 \mathrm{~d}$ \\
$\mathrm{BA}+\mathrm{GA}_{4+7}$ & 25 & $44.35 \mathrm{c}$ & $40.22 \mathrm{~b}$ & $43.82 \mathrm{~cd}$ & $5.32 \mathrm{a}$ \\
$\mathrm{BA}+\mathrm{GA}_{4+7}$ & 50 & $42.61 \mathrm{c}$ & $40.06 \mathrm{~b}$ & $43.32 \mathrm{~d}$ & $3.86 \mathrm{~cd}$ \\
$\mathrm{BA}$ & 50 & $48.20 \mathrm{~b}$ & $41.17 \mathrm{~b}$ & $44.94 \mathrm{bc}$ & $4.69 \mathrm{ab}$ \\
$\mathrm{BA}$ & 100 & $54.33 \mathrm{a}$ & $42.97 \mathrm{a}$ & $47.63 \mathrm{a}$ & $5.27 \mathrm{a}$ \\
$\mathrm{BA}$ & 150 & $51.45 \mathrm{a}$ & $42.54 \mathrm{a}$ & $46.26 \mathrm{~b}$ & $4.45 \mathrm{bc}$ \\
\hline
\end{tabular}

${ }^{2}$ Trees were treated at the end of the third week of May 2009 and 2010 ( $29 \mathrm{~d}$ before harvest). The control was water alone.

${ }^{\mathrm{y}} \mathrm{l} \mathrm{ppm}=1 \mathrm{mg} \cdot \mathrm{L}^{-1}, \mathrm{l} \mathrm{g}=0.0353 \mathrm{oz}, 1 \mathrm{~mm}=0.0394$ inch, $1 \mathrm{lbf}=4.4482 \mathrm{~N}$.

${ }^{\mathrm{x}}$ Means within a column followed by different letters are significantly different at $P \leq 0.05$ by Duncan's multiple range test.

Table 2. Effect of preharvest foliar applications of benzyladenine (BA) and BA + gibberellins $\left(\mathrm{GA}_{4+7}\right)$ on soluble solids content (SSC), $\mathrm{pH}$, and acidity of 'Alyanak' apricot at harvest $(n=80) .^{\mathrm{z}}$

\begin{tabular}{lcccc}
\hline Treatment & Concn $(\mathbf{p p m})^{\mathrm{y}}$ & SSC $(\%)$ & $\mathrm{pH}$ & Titratable acidiy (\%) \\
\hline Control & 0 & 11.68 & 3.51 & $1.51 \mathrm{ab}^{\mathrm{x}}$ \\
$\mathrm{BA}+\mathrm{GA}_{4+7}$ & 12.5 & 13.26 & 3.64 & $1.39 \mathrm{~b}$ \\
$\mathrm{BA}+\mathrm{GA}_{4+7}$ & 25 & 12.42 & 3.59 & $1.50 \mathrm{~b}$ \\
$\mathrm{BA}+\mathrm{GA}_{4+7}$ & 50 & 12.68 & 3.74 & $1.38 \mathrm{~b}$ \\
$\mathrm{BA}$ & 50 & 12.73 & 3.49 & $1.39 \mathrm{~b}$ \\
$\mathrm{BA}$ & 100 & 11.97 & 3.75 & $1.68 \mathrm{a}$ \\
$\mathrm{BA}$ & 150 & 12.55 & 3.60 & $1.37 \mathrm{~b}$ \\
\hline
\end{tabular}

${ }^{2}$ Trees were treated at the end of the third week of May 2009 and 2010 (29 d before harvest). The control was water alone.

${ }^{y} 1 \mathrm{ppm}=1 \mathrm{mg} \cdot \mathrm{L}^{-1}$

${ }^{x}$ Means within a column followed by different letters are significantly different at $P \leq 0.05$ by Duncan's multiple range test.

Orhan, 2009; Einhorn et al., 2013; Facteau, 1986; Kappel and MacDonald, 2002, 2007; Kupferman, 1989; Lenahan et al., 2006; Zhang and Whiting, 2011). Preharvest application of $25 \mathrm{ppm} \mathrm{GA}_{3}$ is a routine treatment in cherry production used to increase the firmness of fruit (Canli and Orhan, 2009). Applications of $\mathrm{GA}_{3}$ reduced the activities of polygalacturonase and pectinmethylesterase enzymes and improved fruit firmness relative to control fruit. Therefore, these enzymes may affect fruit softening in sweet cherry fruit and $\mathrm{GA}_{3}$ may uphold fruit firmness by decreasing activities of these cell wall hydrolytic enzymes (Andrews and Shulin, 1995).

PGR treatments did not affect SSC in this study. Although GA applications significantly increased the SSC compared with control in some fruit crops (Basak et al., 1998; Lenahan et al., 2006; Tuan and Chung-Ruey, 2013), there are reports that the SSC is not always enhanced by preharvest GA sprays and the responses to GA treatment were complex (Choi et al., 2002; Facteau et al., 1985; Horvitz et al., 2003; Kappel and MacDonald, 2002). SSC is affected by environmental factors. Canli and Orhan (2009) reported a significant interaction between $\mathrm{GA}_{3}$ treatment and location with respect to SSC of the sweet cherry fruit.

All of the treatments had the same TA content as the control in this study. Kappel and MacDonald (2002) reported that TA content of $\mathrm{GA}_{3}$-treated sweet cherry fruit was significantly higher than that of control fruit. In contrast to results of Kappel and MacDonald (2002), few researchers reported that $\mathrm{GA}_{3}$ applications reduced TA content of apple (Tuan and Chung-Ruey, 2013) and mandarin fruit (Otmani et al., 2004). Some of the variable responses of fruit to preharvest GA applications is probably due to ecological factors such as precipitation, water status, nutrition, temperature, light, and humidity
(Facteau et al., 1985) or to the use of different genotypes and species (Usenik et al., 2005).

Large and firm apricot fruit are preferred by most consumers. Extending the harvest window by delaying maturity may increase the value of the crop by avoiding lower returns associated with apricot harvested during the peak periods when supplies are overly abundant. The result obtained in this study is the first report on the effect of $\mathrm{BA}$ and $\mathrm{BA}+\mathrm{GA}_{4+7}$ applications on fruit quality of apricot and showed the practical use of a single application of BA at the end of pit hardening for improving apricot size and firmness. To summarize, $100 \mathrm{ppm} \mathrm{BA}$ was the most effective concentration and $100 \mathrm{ppm}$ BA-treated fruit were larger and firmer than untreated fruit. Future studies on the preharvest applications of $\mathrm{BA}$ and $\mathrm{BA}+\mathrm{GA}_{4+7}$ in apricot using different genotypes may give rise to the routine use of these treatments in apricot production.

\section{Literature cited}

Agusti, M., M. Juan, V. Almela, and C. Speroni. 1994. The effect of 2,4-DP on fruit development in apricots (Prunus armeniaca L.). Sci. Hort. 57:51-57.

Andrews, P.K. and L. Shulin. 1995. Cell wall hydrolytic enzyme activity during development of nonclimacteric sweet cherry (Prunus avium L.) fruit. J. Hort. Sci. 70:561-567.

Badanes, M.L., J. Martinez-Calvo, and G. Llacer. 1998. Analysis of apricot germplasm from the European ecogeographical group. Euphytica 102:93-99.

Basak, A., E. Rozpara, and Z. Grzyb. 1998. Use of bioregulators to reduce sweet cherry tree growth and to improve fruit quality. Acta Hort. 468:719-723.

Bhat, M.Y., B.A. Padder, I.A. Wani, F.A. Banday, H. Ahsan, M.A. Dar, and A.A. Lone. 2013. Evaluation of apricot cultivars based on physicochemical characteristics observed under temperate conditions. Intl. J. Agr. Sci. 3:535-537.

Bohner, J. and F. Bangerth. 1988. Cell number, cell size and hormone level in semiisogenic mutants of Lycopersicon pimpinellifolium differing in fruit size. Physiol. Plant. 72:316-320.

Bregoli, A.M., C. Fabbroni, V. Raimondi, and G. Costa. 2010. Improving colour and size of apricot fruit by means of exogenous auxin application. Acta Hort. 862:365-372.

Canli, F.A. and H. Orhan. 2009. Effects of pre-harvest gibberellic acid applications 
on fruit quality of '0900 Ziraat' sweet cherry. HortTechnology 19:127-129.

Choi, C., P.A. Wiersma, P. Toivonen, and F. Kappel. 2002. Fruit growth, firmness and cell wall hydrolytic enzyme activity during development of sweet cherry fruit treated with gibberellic acid $\left(\mathrm{GA}_{3}\right)$. J. Hort. Sci. Biotechnol. 77:615-621.

Clayton, M., W.V. Biasi, I.T. Agar, S.M. Southwick, and E.J. Mitcham. 2006. Sensory quality of 'Bing' sweet cherries following preharvest treatment with hydrogen cyanamide, calcium ammonium nitrate, or gibberellic acid. HortScience 41:745-748.

Demirsoy, L. and S. Bilgener. 2000. The effect of chemical applications on cuticular and epidermal properties of some sweet cherry cultivars with respect to fruit cracking susceptibility. Turk. J. Agr. For. 24:541-550.

Dennis, F.G. 2000. The history of fruit thinning. Plant Growth Regulat. 31:1-16.

Dirlewanger, E., A. Moing, C. Rothan, L. Svanella, V. Pronier, A. Gye, C. Plomion, and R. Monet. 1999. Mapping QTLs controlling fruit quality in peach (Prunus persica (L.) Batsch). Theor. Appl. Genet. 98:18-31.

Einhorn, T.C., Y. Wang, and J. Turner. 2013. Sweet cherry fruit firmness and post-harvest quality of late-maturing cultivars are improved with low-rate, single applications of gibberellic acid. HortScience 48:1010-1017.

Facteau, T.J. 1986. Effects of calcium, GA on cherries studied. Good Fruit Grower 37(9):27-28.

Facteau, T.J., K.E. Rowe, and N.E. Chesnut. 1985. Response patterns of gibberellic acid-treated sweet cherry fruit at different soluble solids levels and leaf/fruit ratios. Sci. Hort. 27:257-262.

Gillaspy, G., H. David, and W. Gruissem. 1993. Fruits: A developmental perspective. Plant Cell 5:1439-1451.

Horvitz, S., C. Godoy, A.F. López Camelo, A. Yommi, and C. Godoy. 2003. Application of gibberellic acid to 'Sweetheart' sweet cherries: Effects on fruit quality at harvest and during cold storage. Acta Hort. 628:311-316.

Jackson, J. 2003. Biology of apples and pears. Cambridge Univ. Press, Cambridge, England.

Ju, Z., Y. Duan, and Z. Ju. 1999. Combinations of GA3 and AVG delay fruit maturation, increase fruit size and improve storage life of 'Feicheng' peaches. J. Hort. Sci. Biotechnol. 74:579-583.

Kappel, F. and R.A. MacDonald. 2002. Gibberellic acid increases fruit firmness, fruit size, and delays maturity of 'Sweetheart' sweet cherry. J. Amer. Pomol. Soc. 56:219-222.

Kappel, F. and R.A. MacDonald. 2007. Early gibberellic acid sprays increase firmness and fruit size of 'Sweetheart' sweet cherry. J. Amer. Pomol. Soc. 61(1):38-43.

Kupferman, E.M. 1989. Cherry warehouse survey shows value of GA use. Good Fruit Grower 40(6):10-13.

Lenahan, O.M., M.D. Whiting, and D.C. Elfving. 2006. Gibberellic acid inhibits floral bud development and improves 'Bing' sweet cherry fruit quality. HortScience 41:654-659.

Mratinic, E., B. Popovski, T. Milosevic, and M. Popovska. 2011. Evaluation of apricot fruit quality and correlations between physical and chemical attributes. Czech J. Food Sci. 2:161-170.

Otmani, M., A. Ait-Oubahou, C.J. Lovatt, F. El-Hassainate, and A. Kaanane. 2004. Effect of gibberellic acid, urea and $\mathrm{KNO}_{3}$ on yield and on composition and nutritional quality of clementine mandarin fruit juice. Acta Hort. 632:149-157.

Ozga, J. and M.D. Reinecke. 2003. Hormonal interactions in fruit development. J. Plant Growth Regulat. 22:73-81.

Pharis, R.P. and R.W. King. 1995. Gibberellic and reproductive development in seed plants. Annu. Rev. Plant Physiol. 36:517-568.

Roussos, P.A., V. Sefferou, N.K. Denaxa, E. Tsantili, and V. Stathis. 2011. Apricot (Prunus armeniaca L.) fruit quality attributes and phytochemicals under different crop load. Sci. Hort. 129:472-478.

Sive, A. and D. Resnizky. 1988. Storage trials with several cherry cultivars in 1987. Alon Hanotea 42:869-877.

Southwick, S.M. and J.T. Yeager. 1995. Use of gibberellin formulations for improved fruit firmness and chemical thinning in 'Patterson' apricot. Acta Hort. 384:425-430.

Stern, A.R., I. Doron, and R. Ben-Arie. 2007. Plant growth regulators increase the fruit size of 'Spadona' and 'Coscia' pears Pyrus communis in a warm climate. J. Hort. Sci. Biotechnol. 82:3-7.
Stern, A.R. and M.A. Flaishman. 2003. Benzyladenine effects on fruit size, fruit thinning and return yield of 'Spodana' and 'Coscia' pear. Sci. Hort. 98:499-504.

Stern, A.R., M.A. Flaishman, and A. Shargal. 2002. Effect of synthetic cytokinin CPPU on fruit size and yield of 'Spodana' pear. Acta Hort. 596:797-801.

Stern, A.R., A. Shargal, and M.A. Flaishman. 2003. Thidiazuron increases fruit size of 'Spadona' and 'Coscia' pear (Pyrus communis L.). J. Hort. Sci. Biotechnol. 78:51-55.

Tuan, N.M. and Y. Chung-Ruey. 2013. Effect of gibberellic acid and 2,4dichlorophenoxyacetic acid on fruit development and fruit quality of wax apple. World Acad. Sci. Eng. Technol. 77:280286.

Usenik, V., D. Kastelec, and F. Stampar. 2005. Physicochemical changes of sweet cherry fruits related to application of gibberellic acid. Food Chem. 90:663-671.

Webster, A.D., J.E. Spencer, C. Dover, and C.J. Atkinson. 2006. The Influence of sprays of gibberellic acid $\left(\mathrm{GA}_{3}\right)$ and aminoethoxyvinylglycine (Avg) on fruit abscission, fruit ripening and quality of two sweet cherry cultivars. Acta Hort. 727:467-472.

Yehia, A.T. and H.S.A. Hassan. 2005. Effect of some chemical treatments on fruiting of "Le Conte" pears. J. Appl. Sci. Res. 1(1):35-42.

Zahedi, M., S. Mortazavi, N. Moallemi, and V. Abdossi. 2013. Effect of preharvest application of gibberellic acid and ethephon on the quality of table grape. J. Ornamental Hort. Plants 3:125-131.

Zhang, C., K. Tanabe, F. Tamura, K. Matsumoto, and A. Yoshido. 2005. ${ }^{13} \mathrm{C}$-photosynthate accumulation in Japanese pear fruit during the period of rapid fruit growth is limited by the sink strength of fruit rather than by transport capacity of the pedicel. J. Expt. Bot. 56:2713-2719.

Zhang, C. and M.D. Whiting. 2011. Improving 'Bing'sweet cherry fruit quality with plant growth regulators. Sci. Hort. 127:341-346.

Zoffoli, J.P., B.A. Latorre, and P. Naranjo. 2009. Preharvest application of growth regulators and their effect on postharvest quality of table grapes during cold storage. Postharvest Biol. Technol. 51:183-192. 